\title{
EVALUASI PENYELENGGARAAN PROGRAM 5000 DOKTOR: STUDI KASUS PADA INSTITUT PTIQ JAKARTA
}

\section{THE EVALUATION OF IMPLEMENTATION PROGRAM OF 5000 DOCTORS: A CASE STUDY IN PTIQ INSTITUTE OF JAKARTA}

\author{
Munawiroh \\ Puslitbang Pendidikan Agama dan Keagamaan Kementerian Agama \\ email: mun.asrori@gmail.com
}

Naskah Diterima: 14 Mei 2019; Direvisi: 23 Agustus 2019; Disetujui: 28 Maret 2020

\begin{abstract}
The research aims to examine and find gaps and alternative solutions to problems, the implementation of the 5000 Doctoral Scholarship Program as a Strategic Program of the Indonesian Ministry of Religion. Therefore, the Center for Research and Education on Religion and Religion needs to evaluate the implementation of the program as the reason for not achieving 5,000 doctors, which is its strategic program. This type of research is evaluation research with a descriptive qualitative approach through an in-depth study of implementing the 5000 doctoral scholarship program at the PTIQ Jakarta Institute. Retrieval of data through interviews, observation, and documentation. The overall research results on the implementation of the scholarship program lectures have been carried out by following the procedures and stages, as stated in the MOU document between the Diktis and the PTIQ Jakarta Institute, both in terms of technical administration and management as well as technical academic implementation. From an administrative point of view, related to costs for students, it needs improvement or adjustment. Besides that, the course time limit is only three years, which becomes an obstacle for students in completing lectures so that graduate quality standards are not met. In academic terms, there is a gap between students from Java and outside Java. This is a result of the recruitment system, which refers to equal distribution/regional representation.
\end{abstract}

Keywords: Evaluation; PTIQ Institute; 5000 Doctoral Program

\begin{abstract}
Abstrak
Penelitian bertujuan untuk mengkaji dan menemukan kesenjangan, serta alternatif pemecahan masalah, penyelenggaraan Program Beasiswa 5000 Doktor sebagai Program Strategis Kementerian Agama RI. Oleh karena itu Pusat Penelitian dan Pendidikan Agama dan Keagamaan perlu melakukan evaluasi pelaksanaan program tersebut sebagai penyebab belum tercapainya 5000 doktor yang merupakan program strategisnya. Jenis penelitian ini adalah penelitian evaluasi dengan pendekatan kualitatif deskriptif, melalui pendalaman tentang penyelenggaraan program beasiswa 5000 doktor di Institut PTIQ Jakarta. Pengambilan data melalui wawancara, observasi dan dokumentasi. Hasil penelitian secara keseluruhan penyelenggaraan perkuliahan program beasiswa tersebut telah dilaksanakan dengan mengikuti prosedur dan tahapan-tahapan sebagaimana tertuang dokumen MOU antara Diktis dan Institut PTIQ Jakarta, baik dalam hal teknis administrasi dan manajemen penyelenggaraan maupun teknis akademis penyelenggaraan. Dari segi administrasi, terkait dengan biaya bagi mahasiswa perlu perbaikan atau penyesuaian, selain itu juga batas waktu perkuliahan yang hanya tiga tahun, menjadi kendala mahasiswa dalam penyelesaian perkuliahan sehingga tidak terpenuhinya standar kualitas lulusan. Pada teknis akademis terjadi kesenjangan antara mahasiswa dari Pulau Jawa dan luar Pulau Jawa, hal tersebut akibat dari sistem rekrutmen yang mengacu pada pemerataan/keterwakilan daerah.
\end{abstract}

Kata Kunci: Evaluasi; Institut PTIQ; Program 5000 Doktor 


\section{PENDAHULUAN}

$\begin{array}{rrr}\text { Program } 5000 & \text { Doktor Kementerian } \\ \text { Agama merupakan program unggulan }\end{array}$ Direktorat Jenderal Pendidikan Islam. Program ini diluncurkan Presiden R.I. pada bulan Desember 2014 di Istana Negara. Program ini bertujuan meningkatkan kapasitas, kapabilitas dan kualitas Sumber Daya Manusia (SDM) pada Kementerian Agama secara umum dan SDM pada Direktorat Jenderal Pendidikan Islam secara khusus. Program 5000 Doktor Kementerian agama, baik untuk PNS maupun Non PNS merupakan program unggulan Direktorat Jenderal Pendidikan Islam. (Basri, 2018)

Perguruan Tinggi Keagamaan Islam (PTKI) di Indonesia dalam perkembangannya menjadi gerbang dakwah nilai-nilai keislaman dalam kehidupan berbangsa dan bernegara. Alumni PTKI telah banyak menempati posisiposisi strategis dalam masyarakat dan menjadi corong keislaman yang handal. Perkembangan PTKI memperlihatkan trend peningkatan jumlah mahasiswa yang diikuti juga oleh perluasan area of studies. Perubahan ini juga diikuti besarnya tantangan dalam berbagai aspek, termasuk menjaga eksistensi PTKI dalam mengawal nilai-nilai kebangsaan dan keagamaan yang selaras (Diktis, 2014).

Program tersebut memiliki dua skema, pertama Skema reguler program 5000 doktor merupakan program yang memberikan kesempatan seluas-luasnya kepada peserta program untuk melanjutkan studi S3 di perguruan tinggi dalam dan luar negeri yang berkualitas, dan kedua skema kerja sama (costumized program) program tersebut merupakan salah satu bentuk akselerasi peningkatan kualitas dosen, tenaga kependidikan, dan pegawai negeri sipil pada Kementerian Agama untuk melanjutkan studi S3 di perguruan tinggi yang telah memiliki kerja sama dengan Kementerian Agama. hal ini menjadi penting sebab pendidikan Islam didesak untuk melakukan inovasi tidak hanya yang bersangkutan dengan kurikulum dan perangkat manajemen, tetapi juga strategi dan taktik operasionalnya. Strategi dan taktik itu, bahkan sampai menuntut perombakan modelmodel sampai dengan institusi-institusinya sehingga lebih efektif dan efisien, dalam arti pedagogis, sosiologis dan kultural dalam menunjukkan perannya (Anwar, 2014). Oleh karena itu program diharapkan dapat melahirkan inovator-inovator untuk melakukan perubahan tersebut. Dengan kata lain Keberhasilan pencapaian tujuan pendidikan merupakan wujud pelaksanaan kinerja dosen. Dosen merupakan salah satu faktor penentu keberhasilan pada sebuah perguruan tinggi. Dosen merupakan salah satu komponen terpenting dalam suatu pendidikan di perguruan tinggi (Syefudin, 2019).

Institut PTIQ (Perguruan Tinggi Ilmu Alquran) merupakan salah satu PTKI yang menjalin kerja sama dengan Kementerian Agama, dengan pertimbangan bahwa, Institut PTIQ adalah perguruan tinggi pertama di dunia yang secara khusus menyelenggarakan program hafalan Alquran dan program kajian ulumul$q u r$ 'an dan bidang terkait dengannya. Dua tahun setelah PTIQ berdiri, Universitas Islam Madinah, Arab Saudi, membuka fakultas khusus ilmu Alquran yang mendapat inspirasi dari didirikannya PTIQ dengan program studi yang diselenggarakannya. Hingga kini Institut PTIQ sudah berkiprah dalam penyelenggaraan Program Studi Alquran dan program terkait dengannya selama lebih dari seperempat abad lalu. Institut PTIQ (dahulu PTIQ) didirikan pada tanggal 1 April 1971, bertempat di Jalan Pasar Jumat, Jakarta Selatan (PTIQ, 2012).

Perguruan Alquran ini didirikan oleh Yayasan Ihya Ulumudin yang dikelola KH. Mohammad Dahlan (Menteri Agama RI tahun 1967-1971), Prof. KH. Ibrahim Hosen, LML, dan KH. Ahmad Zaini Miftach, Imam Besar Masjid Istiqlal saat itu. Selanjutnya pada tanggal 12 Mei 1973 pengelolaan Institut PTIQ ini diserahkan kepada Yayasan Pendidikan Alquran yang didirikan oleh Letjen (Purn.) DR. H. Ibnu Sutowo.

Langkanya ulama ahli Alquran, terutama penghafal Alquran (Hafizhul Qur'an), Kini, pengelolaan Institut PTIQ yang berada di bawah Yayasan Pendidikan Alquran ini diteruskan oleh H. Ponco Susilo Nugroho, salah seorang putra Ibnu Sutowo. Institut PTIQ didirikan dengan dilatarbelakangi oleh kesadaran semakin sedangkan perguruan tinggi yang menyelenggarakan kajian Alquran, tahfizh Alquran dan ilmu terkait dengannya saat itu 
belum ada, disisi lain kebutuhan masyarakat Indonesia akan ulama yang memiliki keahlian di bidang ulumul-Qur'an sangat mendesak. Terlebih lagi sejak penyelenggaraan Musabaqah Tilawatil Qur'an (MTQ) Nasional I di Makassar, pada bulan Ramadhan tahun 1968, kebutuhan akan para ulama ahli Alquran dan huffazhul-qur'an akan terus dirasakan, mengingat antara lain MTQ Nasional merupakan agenda rutin tahunan yang diselenggarakan oleh pemerintah dalam hal ini Kementerian Agama (PTIQ, 2012).

Presiden dalam MTQ Nasional I, mengatakan bahwa, keberadaan para ulama ahli Alquran ini sangat terasa, sehingga Presiden republik Indonesia, Soeharto saat itu, dalam amanatnya pada MTQ Nasional III di Banjarmasin mengingatkan pentingnya meningkatkan upaya penghayatan dan pemahaman kitab suci Alquran sebagai pedoman hidup manusia (Pidato Presiden RI pada MTQ Nasional III di Banjarmasin, 1970).

Sejak berdiri hingga saat ini, lembaga pendidikan tinggi yang berlokasi di Jalan Batan 1/2 (dulu Batan 1/63) Pasar Jumat, Lebak Bulus, Jakarta Selatan ini, secara berturut-turut dipimpin dan dikelola oleh ulama-ulama terkemuka negeri ini. Mereka adalah $\mathrm{KH}$. Mohammad Dahlan, Prof. KH. Ibrahim Hosen, LML, Letjen (Purn.) DR. H. Ibnu Sutowo, KH. Syukri Ghazali, Prof. KH. Zainal Abidin Ahmad, Prof. Dr. KH. Bustami A. Ghani, Prof. Dr. KH. Chatibul Umam dan kini Prof. Dr. H. Nasaruddin Umar, M.A (https://ptiq.ac.id, 2012).

PTIQ pada awalnya hanya memiliki dua fakultas; Syariah dan Ushuluddin. Nama PTIQ juga mengalami beberapa perubahan seiring dengan peraturan perguruan tinggi yang ada. Nama PTIQ pernah berubah menjadi Institut Studi Ilmu Alquran (ISIQ). Untuk mengembalikan nama besar PTIQ, maka kemudian nama itu berubah menjadi Institut Perguruan Tinggi Ilmu Alquran (IPTIQ). Dari perubahan itu, kini PTIQ telah memiliki empat fakultas yaitu Syariah, Ushuluddin, Dakwah, dan Tarbiyah. Selain itu, saat ini PTIQ juga sudah membuka program pascasarjana tingkat S2 dan S3 (https://ptiq.ac.id, 2012).

Sebagai upaya membantu pemerintah dalam penyelenggaraan pendidikan guna mencerdaskan bangsa, dan untuk menampung minat alumni Institut PTIQ yang ingin mengikuti studi lanjut, serta melihat perkembangan kebutuhan masyarakat akan lembaga yang mampu melahirkan ahli dalam Ilmu Agama setingkat Magister, maka dengan mengacu kepada Peraturan Pemerintah Republik Indonesia Nomor 60 Tahun 1999 tentang Pendidikan Tinggi, serta Surat Keputusan Menteri Pendidikan dan Kebudayaan Republik Indonesia nomor 222/U/1998, Institut Perguruan Tinggi Ilmu Alquran Jakarta dengan dukungan tenaga akademik yang ahli di bidangnya dan sarana pendidikan yang dimiliki, pada tahun akademik 1999/2000 telah membuka Program Pascasarjana Ilmu Agama Islam.

Dalam pelaksanaan program tersebut, dengan disadari bahwa Ilmu Agama Islam sebagai ilmu yang berhubungan dengan keagamaan, tidak dapat terlepas dari perkembangan yang terjadi dalam masyarakat, maka Institut PTIQ Jakarta mulai tahun akademik 1999/2000 membuka Program Pascasarjana Ilmu Agama Islam dengan Bidang Kajian atau Konsentrasi Ilmu Tafsir.

Dengan kata lain bahwa Institut PTIQ membuka prodi studi (prodi) tersebut karena masyarakat menginginkannya, mereka menganggap bahwa Alquran merupakan hal yang niscaya karena dibutuhkan baik bagi umat Islam pada umumnya maupun bagi yang memiliki kesungguhan untuk mempelajari Alquran, memahami dan mengamalkannya dalam hidup sehari-hari. Para pakar ahli yang berkecimpung dalam penafsiran terhadap ayatayat Alquran berupaya untuk selalu melakukan pembaharuan dalam penafsirannya supaya dapat menjawab persoalan-persoalan yang berkembang di masyarakat (Umayah, 2016). Ketika prodi tersebut dibuka pemintanya sangat banyak. Ketika PTIQ mendapat tawaran untuk bekerja sama dalam pelaksanaan program beasiswa, semakin banyak pula pemintanya, meskipun yang peserta yang lulus terbatas.

Pada tahun 2005, Lembaga Pendidikan Islam mengalami perkembangan pesat. Di samping pesantren yang pada umumnya terletak di pedesaan, lembaga-lembaga pendidikan di perkotaan, makin banyak bermunculan lembaga sejenis ini dari tingkat Play Group hingga 
perguruan tinggi. Perkembangan ini tentu memerlukan tenaga pengelola lembaga pendidikan yang handal sesuai dengan karakteristik Islam.

Untuk menjawab kebutuhan tersebut dan berdasarkan Surat Perpanjangan Izin No. Dj.II/104/2006, pada tahun akademik 2005/2006 Program Pascasarjana Institut PTIQ Jakarta membuka Konsentrasi Manajemen Pendidikan Islam (MPI). Berbekal Surat Izin Penyelenggaraan Program Magister Pendidikan Islam Dj.I/315/2009 tanggal 4 Juni 2009; Status Terakreditasi dari Badan Akreditasi Nasional Perguruan Tinggi (BAN-PT) Nomor: 005/BAN-PT/Ak-VII/S2/VI/2009 tanggal 26 Juni 2009; dan Surat Perpanjangan Izin Penyelenggaraan Program Magister Ilmu Agama Islam No. Dj.I/618/2009 tanggal 23 Oktober 2009, Institut PTIQ Jakarta mengajukan proposal pembukaan Program Doktor (S3) bidang Kajian Islam dengan Konsentrasi Ilmu Tafsir (IT) dan Pendidikan Alquran (MPI). Namun karena adanya perubahan peraturan yang ada, ijin penyelenggaraan program Doktor Institut PTIQ Jakarta turun dengan SK No. 853 tahun 2012, untuk program Doktor Studi Ilmu Alquran dan Tafsir (Dok. Admin PTIQ, 2012).

Saat ini, seluruh program studi pada Program Pascasarjana Institut PTIQ Jakarta telah mendapatkan Akreditasi BAN-PT. Baik Magister Ilmu Agama Islam, Magister Pendidikan Islam, dan Doktor Ilmu Alquran dan Tafsir. Berikut adalah bukti keterangan Akreditasi BAN-PT untuk masing-masing program studi. Untuk S2 Magister Ilmu Agama Islam, Nomor: 438/SK/BANPT/Akred/M/XI/2014 Tanggal 2 November 2014, S2 Magister Pendidikan Islam, Nomor: 238/SK/BAN-PT/Ak-XI/M/XI/2013 Tanggal 22 November 2013 dan S3 Doktor Ilmu Alquran dan Tafsir, Nomor: 120/SK/BANPT/Akred/D/III/2015 Tanggal 28 Maret 2015. (Wawancara dengan Prof. Dr. M. Darwis Hude, M.Si (Direktur Pascasarjana Istitut PTIQ Jakarta) tanggal, 25 Oktober 2018)

Demi legalitas sebuah penyelenggaraan pendidikan, Program Pascasarjana Institut PTIQ Jakarta juga telah mendapatkan Izin Penyelenggaraan Program Studi dari Direktorat Pendidikan Islam Kementerian Agama RI.
Berikut keterangan Izin Penyelenggaraan untuk masing-masing program studi, diantaranya, yaitu S2 Magister Ilmu Agama Islam, Nomor: 4383 Tahun 2016, Tanggal 8 Agustus 2016, S2 Magister Pendidikan Islam, Nomor: 4383 Tahun 2016, Tanggal 8 Agustus 2016, dan S3 Doktor Ilmu Alquran dan Tafsir, Nomor: 4384 Tahun 2016, Tanggal 8 Agustus 2016.

Dalam penyelenggaraan pendidikan tentunya Institut PTIQ dilandaskan pada nilai dasar, visi, misi dan tujuan yang telah direncanakan dalam Rencana Induk Pengembangan (RIP) hingga tahun 2020. Adapun nilai dasar, visi, misinya dan tujuan Institut, yaitu pertama, Nilai Dasar Institut PTIQ Jakarta adalah keterpaduan antara nilai pengabdian (ibadah) dan nilai keunggulan yang dijadikan landasan utama dalam membangun visi dan misi, kedua, Visi Institut adalah, Terwujudnya Lembaga Pendidikan Tinggi yang unggul dalam pengkajian dan pengembangan keilmuan berbasis Alquran, ketiga, Misi Institut, yaitu 1) Menyelenggarakan pendidikan tinggi secara profesional berlandaskan nilainilai Alquran, 2) Mengembangkan ilmu-ilmu sosial, seni, budaya dan teknologi berbasis Alquran, 3) Menyelenggarakan penelitian dan pengabdian masyarakat secara profesional dalam pengembangan keilmuan Islam dan teknologi berbasis Alquran, dan 4) Menjalin kerja sama dengan berbagai lembaga di tingkat Regional, Nasional dan Internasional.

Tujuan Institut, yaitu 1) Menghasilkan sarjana dan ilmuwan yang memiliki kapabilitas dan integritas sesuai dengan nilai-nilai Alquran, 2) Menghasilkan sarjana yang berilmu amaliyah, beramal ilmiah serta berakhlakul karimah mampu memahami dan mengaktualisasikan nilai-nilai Alquran, 3) Menghasilkan penelitian yang unggul dan dipublikasikan pada level nasional dan internasional, 4) Menghasilkan karya-karya pengabdian pada masyarakat yang aktual dan aplikatif, dan 5) Merealisasikan segala bentuk kerja sama dengan berbagai lembaga di tingkat Regional, Nasional dan Internasional. (Dokumen Admin pascasarjana).

Untuk mengetahui lebih lanjut penyelenggaraan Program 5000 Doktor pada Institut PTIQ Jakarta, maka perlu dilakukan evaluasi implementasi program tersebut 
mengingat telah berlangsung sejak tahun 2016. Mengingat program beasiswa ini sebagai kegiatan strategis Kementerian Agama, maka penting untuk dilakukan penelitian atas pelaksanaan program tersebut yang diselenggarakan oleh Institut PTIQ untuk mengevaluasi capaian-capaian yang telah dilaksanakan, dibandingkan dengan tujuan yang telah direncanakan sebelumnya. Adapun pertanyaan penelitian ini adalah: bagaimana penyelenggaraan program beasiswa 5000 doktor di PTIQ, dan apa kendala yang dihadapi dalam penyelenggaraan tersebut.

Adapun penelitian ini bertujuan untuk mengkaji secara mendalam pelaksanaan Program 5.000 Doktor pada Perguruan Tinggi, mencermati dan menemukan kesenjangan antara konsepsi dengan pelaksanaannya di lapangan, menemukan alternatif pemecahan atau penyelesaian untuk pelaksanaan program selanjutnya, dan mengukur keberhasilan pelaksanaan program sebagai program strategis Kementerian Agama.

Hasil evaluasi tersebut dapat dijadikan dasar pijakan untuk melakukan perbaikan atau mencarikan solusi/ pemecahan permasalahannya. Hasil penelitian ini juga dimaksudkan untuk bahan bagi program pengembangan SDM Kementerian Agama melalui program-program beasiswa, sekaligus sebagai review atau tinjauan seberapa besar ketercapaian program strategis dalam hal pengembangan SDM Kementerian Agama.

\section{KAJIAN TEORI}

Secara etimologi "evaluasi" berasal dan bahasa Inggris yaitu evaluation dari akar kata value yang berarti nilai atau harga. Nilai dalam bahasa Arab disebut alqiamah atau al-taqdir' yang bermakna penilaian (evaluasi). Sedangkan secara harfiah, evaluasi pendidikan dalam bahasa Arab sering disebut dengan al-taqdir altarbiyah yang diartikan sebagai penilaian dalam bidang pendidikan atau penilaian mengenai hal yang berkaitan dengan kegiatan pendidikan (Mahirah B., 2017).

Evaluasi merupakan bagian dari sistem manajemen yaitu perencanaan, organisasi, pelaksanaan, monitoring dan evaluasi. Tanpa evaluasi, maka tidak akan diketahui bagaimana kondisi objek evaluasi tersebut dalam rancangan, pelaksanaan serta hasilnya. Istilah evaluasi sudah menjadi kosa kata dalam bahasa Indonesia, akan tetapi kata ini adalah kata serapan dari bahasa Inggris yaitu evaluation yang berarti penilaian atau penaksiran (Echols \& Shadily, 2000). Sedangkan menurut pengertian istilah "evaluasi merupakan kegiatan yang terencana untuk mengetahui keadaan sesuatu obyek dengan menggunakan instrumen dan hasilnya dibandingkan dengan tolak ukur untuk memperoleh kesimpulan (Yunanda, 2009). Sedang menurut Mardapi (2005), bahwa secara umum evaluasi merupakan proses mengumpulkan informasi untuk mengetahui pencapaian belajar peserta didik. Evaluasi proses dan hasil belajar bertujuan untuk menentukan tingkat ketercapaian tujuan pendidikan yang telah ditetapkan (Aman, 2012).

Evaluasi yang sering dipahami selama ini dalam dunia pendidikan adalah terbatas pada penilaian saja. Penilaian ini dilakukan secara formatif dan sumatif. Ketika sudah dilakukan penilaian, dianggap sudah melakukan evaluasi. Pemahaman demikian tidaklah terlalu tepat. Pelaksanaan penilaian cenderung hanya melihat capaian tujuan pembelajaran saja. Pada hal, dalam proses pendidikan tersebut bukan hanya nilai yang dilihat, tetapi ada banyak faktor yang membuat berhasil atau tidaknya sebuah program. Penilaian hanya bagian kecil dari evaluasi. Evaluasi juga harus dipahami sebagai bagian dari supervise (Divayana, 2016)

Pemahaman mengenai pengertian evaluasi dapat berbeda-beda sesuai dengan pengertian evaluasi yang bervariatif oleh para pakar evaluasi. Menurut Stufflebeam (1968), evaluasi merupakan proses menggambarkan, memperoleh, dan menyajikan informasi yang berguna untuk merumuskan suatu alternatif keputusan. Worthen dan Sanders (1973) mendefinisikan sesuatu yang berharga tersebut dapat berupa informasi tentang suatu program, produksi serta alternatif prosedur tertentu. Sementara Tague-Sutcliffe (1996), mengartikan evaluasi sebagai bagian "a systematic process of determining the extent to which instructional objective are achieved by pupils". Evaluasi dapat juga didefinisikan sebagai penilaian pencapaian tujuan melalui pengumpulan dan analisis data yang berguna untuk membuat 
keputusan dari suatu program. Model evaluasi berguna dalam membimbing pengelolaan, pengumpulan data dan analisis (Woods, 1988).

Dalam Arikunto dan Jabar (2010), bahwa evaluasi adalah kegiatan untuk mengumpulkan informasi tentang bekerjanya sesuatu, yang selanjutnya informasi tersebut digunakan untuk menentukan alternatif yang tepat dalam mengambil sebuah keputusan. Fungsi utama evaluasi dalam hal ini adalah menyediakan informasi-informasi yang berguna bagi pihak decision maker untuk menentukan kebijakan yang akan diambil berdasarkan evaluasi yang telah dilakukan. Sedangkan Usman (2003) mengatakan bahwa evaluasi adalah suatu proses yang ditempuh seseorang untuk memperoleh informasi yang berguna untuk menentukan mana dari dua hal atau lebih yang merupakan alternatif yang diinginkan, karena penentuan atau keputusan semacam ini tidak diambil secara acak, maka alternatif-alternatif itu harus diberi nilai relatif, karenanya pemberian nilai itu harus memerlukan pertimbangan yang rasional berdasarkan informasi untuk proses pengambilan keputusan.

Menurut Djaali dan Muljono (2008), evaluasi dapat juga diartikan sebagai proses menilai sesuatu berdasarkan kriteria atau tujuan yang telah ditetapkan yang selanjutnya diikuti dengan pengambilan keputusan atas obyek yang dievaluasi. Sedangkan Sudjana dan Rivai (2009), mengatakan bahwa evaluasi diartikan sebagai proses sistematis untuk menentukan nilai sesuatu (ketentuan, kegiatan, keputusan, unjuk kerja, proses, orang, obyek, dll.) berdasarkan kriteria tertentu melalui penilaian. Untuk menentukan nilai sesuatu dengan cara membandingkan dengan kriteria, evaluator dapat langsung membandingkan dengan kriteria namun dapat pula melakukan pengukuran terhadap sesuatu yang dievaluasi kemudian baru membandingkannya dengan kriteria.

Brinkerhoff mengemukakan tiga pendekatan evaluasi yang disusun berdasarkan penggabungan elemen-elemen yang sama, yaitu (1) fixed vs emergent evaluation design. Desain evaluasi yang baik ditentukan dan direncanakan secara sistematik sebelum implementasi dikerjakan. Desain dikembangkan berdasarkan tujuan program disertai seperangkat pertanyaan yang akan dijawab informasi yang akan diperoleh dari sumber-sumber tertentu. Rencana analisis dibuat sebelumnya yang Pemakainya akan menerima informasi seperti yang telah ditentukan dalam tujuan. Desain ini dapat disesuaikan dengan kebutuhan yang mungkin. (2) formative vs sumative evaluation. Evaluasi formatif digunakan untuk memperoleh informasi yang dapat membantu memperbaiki program, dilaksanakan pada saat implementasi program sedang berjalan. Fokus evaluasi berkisar Pada kebutuhan yang telah dirumuskan oleh evaluator. Evaluasi Sumatif dilaksanakan untuk menilai suatu program, dari hasil evaluasi ini dapat ditentukan apakah suatu program tertentu akan diteruskan atau dihentikan. Pada evaluasi sumatif difokuskan Pada variabel yang penting bagi pembuat keputusan. Waktu pelaksanaan evaluasi sumatif pada akhir program. (3) Experimental \& quasiexperimental designs vs. UnobtrusiveInquiry. Beberapa evaluasi memakai metodologi penelitian klasik, dalam hal seperti ini penelitian diacak, perlakuan diberikan dan pengukuran dampak dilakukan (Brinkerhoff et al., 1983). Tujuan dari penelitian untuk menilai manfaat suatu program yang dicobakan. Apabila siswa atau program dipilih secara acak, maka generalisasi dibuat pada populasi yang agak lebih luas. Dalam beberapa hal intervensi tidak mungkin dilakukan atau tidak. proses sudah diperbaiki. Evaluator harus melihat dokumen, seperti mempelajari nilai tes atau menganalisis penelitian yang dilakukan dan lainnya. Strategi pengumpulan data terutama menggunakan instrumen formal seperti tes, survei, kuesioner serta memakai metode penelitian yang terstandar (Wahyudhiana, 2015)

Menurut Sudjana dalam Lazwardi (2017), dalam model evaluasi program mencakup lebih dari 50 jenis yang telah dan sedang digunakan dalam evaluasi program. Sebagian model berupa rancangan teoritis yang disusun para pakar, sebagian dikembangkan dari pengalaman evaluasi di lapangan dan sebagian lagi berupa konsep, pedoman dan petunjuk teknis untuk menyelenggarakan evaluasi program

Hasil evaluasi yang dilaporkan bersifat deskripsi dan interpretasi, bukan pengukuran dan prediksi. Oleh karena itu, dalam pelaksanaan evaluasi model yang keempat ini 
lebih banyak menekankan pada penggunaan judgement. Perbedaan penelitian (akademik) dengan penelitian evaluasi adalah bahwa pada evaluasi diperlukan adanya kriteria. Memberikan nilai terhadap objek yang dievaluasinya. Evaluasi program mempunyai fungsi menyediakan informasi yang digunakan untuk membantu pembuatan keputusan dalam penyusunan kebijakan maupun penyusunan program selanjutnya agar keputusan yang dihasilkan menjadi keputusan yang baik.

Asumsi yang dibangun dalam pemikiran ini bahwa keputusan yang baik membutuhkan informasi yang lengkap, akurat, dan dapat dipercaya (valid, dan reliable) serta tepat Waktu (timely). Informasi yang lengkap mempunyai makna bahwa informasi yang dihasilkan dari evaluasi mencakup komponen-komponen program secara lengkap. Informasi yang akurat mempunyai makna bahwa informasi merupakan informasi yang tepat menggambarkan keadaan yang sebenarnya dari objek evaluasi dan dapat dipercaya (M Darodjat, 2015).

Untuk mendapatkan informasi yang akurat dibutuhkan instrumen pengumpulan data yang valid dan reliable. Informasi yang tepat waktu mempunyai makna bahwa informasi yang diperoleh dari hasil evaluasi dapat disampaikan kepada pihak-pihak yang membutuhkan, untuk mengambil keputusan, menyusun kebijakan maupun menyusun program selanjutnya. Syarat ketepatan waktu ini berkaitan dengan kepraktisan dalam pengumpulan, pengolahan, dan penyajian informasi. Oleh karenanya evaluasi berperan penting dalam keseluruhan program kebijakan, pembelajaran, dan Pendidikan, termasuk pada program penguatan sumber daya manusia (Aryanti \& Supriyono, 2015).

Dengan demikian evaluasi tidak selalu melalui proses mengukur baru melakukan proses menilai tetapi dapat pula evaluasi langsung melalui penilaian saja. Hal ini sejalan dengan apa yang dikemukakan Crawford (2000), mengartikan penilaian sebagai suatu proses untuk mengetahui apakah suatu kegiatan, proses kegiatan, keluaran suatu program telah sesuai dengan tujuan atau kriteria yang telah ditentukan.
Dari definisi evaluasi di atas dapat ditarik kesimpulan bahwa evaluasi adalah penerapan prosedur ilmiah yang sistematis untuk menilai rancangan, selanjutnya menyajikan informasi dalam rangka pengambilan keputusan terhadap implementasi dan efektivitas suatu program. Evaluasi meliputi mengukur dan menilai yang digunakan dalam rangka pengambilan keputusan. Hubungan antara pengukuran dan penilaian saling berkaitan. Mengukur pada hakikatnya adalah membandingkan sesuatu dengan atau atas dasar ukuran atau kriteria tertentu (meter, kilogram, takaran dan sebagainya), pengukuran bersifat kuantitatif. Penilaian berarti menilai sesuatu. Sedangkan menilai itu mengandung arti, mengambil keputusan terhadap sesuatu yang berdasarkan pada ukuran baik atau buruk, sehat atau sakit, pandai atau bodoh dan sebagainya.

Mengingat Peranan dan kegunaan evaluasi yang dirasa sangat penting, maka para perancang dan pelaksana program serta evaluator program harus memahami konsep evaluasi dan peranannya dalam keseluruhan program pelatihan, menindaklanjuti hal tersebut peneliti secara eksploratif akan mengkaji secara mendalam mengenai pelaksanaan Program 5000 Doktor di Institut PTIQ Jakarta.

\section{METODOLOGI}

Penelitian ini dilakukan di Institut PTIQ Jakarta yang beralamatkan di Jl. Batan I No. 63 Rt 02/02 Pasar Jumat Jakarta Selatan. Penelitian dilaksanakan selama dua belas hari kerja pada bulan Oktober 2018. Penelitian ini merupakan penelitian evaluatif dengan pendekatan kualitatif. Dimana penelitian kualitatif merupakan suatu penelitian yang ditujukan untuk mendeskripsikan dan menganalisis fenomena, peristiwa, aktivitas sosial, sikap, kepercayaan, persepsi, pemikiran orang secara individual maupun kelompok. Beberapa deskripsi digunakan untuk menemukan prinsipprinsip dan penjelasan yang mengarah pada penyimpulan (Sukmadinata, 2007).

Teknik pengumpulan data yang peneliti lakukan dengan menggunakan metode observasi, wawancara, dan dokumen, untuk mendapatkan informasi yang benar dan akurat, sehingga kebenaran informasi data yang diperoleh dapat dipertanggungjawabkan. 
Sumber data dalam penelitian ini adalah informan kunci yang bertujuan untuk menggali informasi yang relevan dengan penelitian ini. Diantara informan kunci tersebut adalah Direktur Program Pasca Sarjana Institut PTIQ, selain itu peneliti juga menentukan informan tambahan sebagai sumber informasi lainnya, yaitu ketua program studi S3 Ilmu Alquran dan Tafsir; dan mahasiswa Program Beasiswa 5000 Doktor.

Analisis data dalam penelitian ini adalah menggunakan metode kualitatif, dimana proses mencari dan menyusun data secara sistematis diperoleh dari hasil wawancara, catatan lapangan, dan dokumentasi, dengan cara mengorganisasikan data ke dalam kategori, menjabarkan ke dalam unit-unit, melakukan sintesa, dan membuat kesimpulan sehingga mudah dipahami oleh diri sendiri maupun orang lain (Sugiono, 2017).

Data yang dianalisis dalam penelitian ini adalah hasil kajian para ahli pendidikan dan juga hasil wawancara dengan Direktur Pascasarjana Institut PTIQ, Ketua Program Studi Ilmu Alquran dan Tafsir, sekaligus sebagai Koordinator Program beasiswa serta Mahasiswa yang mendapat Program Beasiswa 5000 Doktor Institut PTIQ, serta hasil observasi terhadap pembelajaran yang sedang berlangsung. Selain itu data dokumentasi tentang profil PTIQ, dokumen administrasi dan akademik terkait dengan program beasiswa. Secara metodologis lingkup penelitiannya, yaitu penyelenggaraan program, kuantitas dan kuantitas lulusan sesuai target yang dirancang.

\section{HASIL DAN PEMBAHASAN}

\section{Keberadaan Mahasiswa, Kurikulum dan Dosen}

Melalui hasil rekrutmen baik tes tertulis dan wawancara mahasiswa yang lulus pada program 5000 Doktor pada tahun 2016/2017 sebanyak 15 dosen dari perwakilan PTKI Jakarta, Jawa Barat, Jawa Tengah, Jawa Timur, Sumatera Barat, Sumatera Selatan, Riau, dan Bangka Belitung. Sedang pada tahun 2017/2018 sebanyak 13 dosen perwakilan PTKI Banten, Jawa Barat, Jawa Tengah, Jawa Timur, Sumatera Utara, Sumatera Barat, Riau dan Sulawesi Tengah. Untuk tahun ajaran 2018/2019 sebanyak 13 dosen PTKI yang lulus mengikuti program doktor di Institut PTIQ Jakarta, adalah perwakilan dari Banten, Jawa Tengah, Jawa Timur, Lampung, Sumatera Barat, dan Kalimantan Selatan. Lebih lanjut tergambar pada tabel berikut.

Tabel 1. Daftar nama peserta program doktor di Institut PTIQ tahun 2016-2018

\begin{tabular}{lll}
\hline \multicolumn{1}{c}{ Tahun 2016 } & \multicolumn{1}{c}{ Tahun 2017 } & \multicolumn{1}{c}{ Tahun 2018 } \\
\hline Adudin Wijaya & Achmad Muhammad & Ahmad Bahrul Hikam \\
Deddy Ilyas & Ahmad Ari Mansyuri & Ahmad Rijali Elmi \\
Dedy Kusuma Wardani & Ahmad Badrudin & Daiyyana Sari \\
Faizin & Ahmad Nurfathoni & Hamzah \\
Ina Salmah Febriani & Aldomi Putra & Muhammad Zainal Arifin \\
Iqrom Faldiyansah & Ali Machfudz & M. Iqbal Khomaini \\
Jauhar Hatta & Amdahurifky B & Muhamad Zainul Abidin \\
Juhdi Rifai & Dewi Murni & Muhammad Amin \\
Luqman & Fahmi A Jawwas & Muhammad Amirullah \\
Muhammad Taufiq & Jufri Hasani Z & Muhammad Lazim \\
Nandar Sunandar & Miftah Ulya & Nurkholis \\
Niila Khoiru Amalia & Moh. Bakir & Otong Suhendar \\
Nurlizam & Subur Wijaya & Riddo Andini \\
Ratoni & & \\
Zainal Arif & & \\
\hline
\end{tabular}

Untuk kurikulum dan dosen terkait dengan program beasiswa 5000 doktor pada Institut PTIQ Jakarta dengan Studi Ilmu
Alquran dan Tafsir, yaitu: 1) Metode Ilmu Tafsir, dengan mata kuliah terdiri dari 10 Pokok Bahasan, antara lain Tafsir: Pengertian dasar 
dan urgensinya, Konsep Dasar Metodologi Tafsir, Teknik Analisis Tafsir, Teknik Interpretasi dalam Penafsiran, Pendekatan Kajian Tafsir, Metode Penulisan, Proposal Penelitian, Jenis-Jenis Metode Kualitatif. 2) Quranic World View, pada mata kuliah ini terdiri dari Alquran dan Perubahan Sosial di Indonesia, Islam dan Gender, Alquran dan Komunikasi, Studi Alquran Kontemporer, Alquran dan Peradaban Manusia, Alquran dan dinamika pemikiran Islam, dan Alquran dan Psikologi. 3) Ulumul Qur'an, pokok bahasan ini terdiri dari: Ilmu-ilmu Alquran, Kaidah-kaidah yang diperlukan para mufasir, Perbedaan Muhkam dan Mutasyabih, 'Âmm dan Khâshsh, Nâsikh Mansûkh, Mutlaq dan Muqayyad, Mantuq dan Mafhum, Amtsâl Alquran, QasamQasam Alquran, Kemukjizatan Alquran, Jadal dalam Alquran, Kisah-kisah Alquran, Pertumbuhan dan Perkembangan Tafsir, dan Dinamika Metode Tafsir Kontemporer. 4) Filsafat Ilmu, Pokok bahasan ini terdiri dari Pengertian Filsafat Ilmu, Filsafat Ilmu dan Agama, Sejarah perkembangan ilmu filsafat, metafisika ilmu dan epistemologi, Pandangan dunia modern dan Islam terhadap ilmu, Paradigma sains positifisme modern dan postmodern, Epistemologi hermeneutika dan fenomenologi, Epistemologi ilmu dalam kerangka pemikiran Islam, Penciptaan Alam Raya, Penciptaan Manusia, Transformasi Filsafat Yunani Kuno ke Filsafat Islam, Metafisika dan Kebenaran Ilmiah, Nuklir dan revolusi genetika dalam perspektif Islam, nuklir dan revolusi genetika dalam perspektif Islam, Islam dan psikologi, dan Manusia dan Sumber Daya Alam. Selain pokok bahasan di atas ada mata kuliah umum, Alquran dan Sains dengan pokok bahasan, yaitu Pengantar Alquran dan Sains, Alquran dan Psikologi, Alquran dan Geologi, Alquran dan Oceanografi, Alquran dan Astronomi, Alquran dan Hidrologi, Alquran dan Astrofisika, Alquran dan Arkeologi, dan Alquran dan Sejarah Keagamaan.

Dari mata kuliah dan pokok bahasan tersebut di atas, jumlah SKS yang harus diselesaikan oleh mahasiswa adalah 50 SKS. Dosen yang mengampu seluruh mata kuliah berjumlah 37 orang terdiri dari 8 orang Guru Besar, 22 orang Doktor (S3) dan 7 orang dosen tamu. Dengan demikian standar penyelesaian program doktor sudah terpenuhi baik dari segi SKS, kurikulum dan dosen pengampunya. Dengan data-data tersebut, komposisi dosen pengampu berdasarkan kualifikasi akademis sudah terpenuhi, tinggal penyusunan pembagian mata kuliah dengan kualifikasi keahlian masing-masing dosen perlu diberikan kriteria khusus, sebanding dengan jumlah 50 SKS yang harus ditempuh mahasiswa.

\section{Pelaksanaan Program Doktor}

Sebagai realisasi dari Program 5000 Doktor. dalam tataran administrasi penyelenggaraan kegiatan tersebut, melalui mekanisme kerja sama antara Diktis dan Perguruan Tinggi Penyelenggara yang telah memenuhi persyaratan yang telah ditetapkan. Diantara persyaratan yang harus dipenuhi, bahwa Institut PTIQ memiliki calon supervisor ahli dalam bidang yang akan dipelajari, dan memiliki reputasi baik berdasarkan ranking perguruan tinggi. Dalam hal anggaran penyelenggaraannya melalui mekanisme sebagai berikut.

MOU No. 4491 Tahun 2016, ditandatangani oleh pihak pertama (mewakili Diktis) dilakukan oleh Prof. Dr. H. Amsal Bakhtiar, MA dengan pihak kedua Prof. Dr. HM. Darwis Hade, M.Si selaku Direktur Pasca Sarjana Institut PTIQ. Jumlah total beasiswa Rp 3.481.500.000, dari total biaya di atas dirinci menjadi empat komponen pembiayaan, yaitu biaya pendaftaran dan seleksi Rp 11.280.000, biaya pendidikan $\mathrm{Rp} 1.045 .850 .000$, biaya mahasiswa $\mathrm{Rp} 1.873 .000 .000$, dan biaya penyelenggaraan program $\mathrm{Rp}$ 193.050.000.

MOU No. 5197 Tahun 2017, ditanda tangani oleh pihak pertama (mewakili Diktis dilakukan oleh Dr. Imam Syafe'I, M.Pd dengan pihak kedua Prof. Dr. HM. Darwis Hade, M.Si selaku Direktur Pasca Sarjana Institut PTIQ. Jumlah total beasiswa Rp 2.702.700.000, dari total biaya di atas dirinci menjadi empat komponen pembiayaan, yaitu pendaftaran dan seleksi 9.750.000, biaya pendidikan Rp 637.900.000, biaya mahasiswa $\mathrm{Rp}$ 1.872.000.000, dan biaya penyelenggaraan program Rp 193.050.000.

MUO No. 4717 Tahun 2018, ditandatangani oleh pihak pertama (mewakili Diktis dilakukan oleh Prof. Dr. M. Arskal Salim 
GP, M.Ag dengan pihak kedua Prof. Dr. HM. Darwis Hade, M.Si, selaku Direktur Pasca Sarjana Institut PTIQ. Jumlah total beasiswa Rp 3.110.900.000, dari total biaya di atas dirinci, yaitu biaya pendidikan $\operatorname{Rp} 1.045 .850 .000$, biaya mahasiswa $\mathrm{Rp}$ 1.873.000.000, dan biaya penyelenggaraan program $\mathrm{Rp}$ 193.050.000.

Dilihat dari alokasi anggaran di atas unit cost per orang selama menempuh pendidikan selama 3 tahun $\pm \mathrm{Rp} 230.000 .000$, biaya penyelenggaraan unit cost per orang $\pm \mathrm{Rp}$ 88.000.000, dan biaya mahasiswa per orang $\pm \mathrm{Rp}$ 144.000.000. Dari biaya mahasiswa apabila dirinci per bulan mahasiswa mendapatkan biaya tunjangan hidup sebesar Rp 4.000.000 (makan, tempat tinggal, transport, beli buku, dan penelitian). Selebihnya merupakan biaya perkuliahan yang diserahkan kepada lembaga PTIQ.

Hal tersebut di atas menjadikan pertimbangan bagi para dosen untuk ikut berkompetisi dalam program doktor dimaksud, terutama bagi dosen peserta program yang berada di luar Jakarta, mengingat minimnya biaya yang diterima sangat minim. Minim diartikan kurang memadai mengingat mahasiswa yang dari luar jakarta mereka perlu tempat tinggal dan biaya hidup, sementara mereka juga meninggalkan keluarga di kampung. Sementara ketika para dosen peserta program lulus, mereka mendapat surat pembebasan tugas dari institusinya sekaligus juga pembebasan dari tunjangan-tunjangan lainnya, mereka hanya menerima gaji bulanan saja. Oleh karenanya biaya yang diterima setiap bulannya tidak mencukupi.

Biaya mahasiswa tersebut yang menjadi keluhan bagi mahasiswa, mengingat biaya hidup di Jakarta bisa dibilang mahal. Untuk mengatasi hal tersebut sebagian mahasiswa ada yang membuka les privat, khotib, penceramah, dll. Sebagai penyambung hidup, dengan kegiatan tambahan dimaksud para dosen peserta program menjadi kurang maksimal dalam mengikuti proses pembelajaran, dampaknya adalah mereka bisa menyelesaikan/lulus sesuai dengan yang di targetkan namun dengan nilai yang memuaskan (B) dan tidak yang sangat memuaskan (A). meskipun ada di antara mereka yang mendapatkan nilai A. Terkait dengan batas waktu tiga tahun yang ditetapkan juga menjadi pertimbangan bagi mahasiswa untuk bisa mencapai kelulusan yang maksimal. Mengingat waktu 3 tahun, menurut mahasiswa sangat singkat, apalagi bagi mahasiswa yang berasal dari Pulau Jawa merasa sangat kesulitan, mengingat mahasiswa yang dari luar jawa setelah selesai perkuliahan selama \pm 2 tahun mereka kembali ke daerah masing-masing dan kembali beraktivitas di kampus otomatis penyelesaian disertasi menjadi terhambat, dan ketika mereka tetap tinggal di Jakarta, mereka merasa kesulitan terkait dengan beban biaya yang mereka keluarkan.

\section{Rekrutmen Mahasiswa}

Dalam hal rekrutmen calon mahasiswa Program 5000 Doktor yang diselenggarakan oleh Institut PTIQ, mengikuti ketentuan seperti tertuang dalam MOU yaitu pelaksanaan tes diselenggarakan oleh Perguruan Tinggi Penyelenggara Program 5000 Doktor. Mahasiswa dengan nilai 10 tertinggi dinyatakan lulus untuk mengikuti program tersebut dengan memperoleh bea siswa dari Diktis. Namun demikian cara seleksi tersebut dinilai kurang tepat sasaran karena mahasiswa peserta tes program ini hanya diikuti oleh peserta dari Perguruan Tinggi di Pulau Jawa tanpa mengikut-sertakan mahasiswa dari luar Pulau Jawa. Dengan demikian program strategis Kemenag tidak memenuhi sasaran karena ketidak terwakilinya mahasiswa calon penerima beasiswa dari luar pulau Jawa.

Belajar dari pengalaman rekrutmen pada tahun 2016, pada Tahun 2017 dan 2018 ada perubahan dalam sistem rekrutmen mahasiswa penerima beasiswa ini. Seleksi penerimaan diselenggarakan langsung oleh Diktis dengan bahan ujian dari masing-masing Perguruan Tinggi penyelenggara sesuai dengan program studinya. Pesertanya tidak hanya mahasiswa perguruan tinggi yang berada di Pulau Jawa, melainkan mengikut sertakan mahasiswa dari perguruan tinggi di luar Pulau Jawa. Hasil tes dengan nilai 5 tertinggi dapat diterima di Perguruan Penyelenggara tempat mahasiswa mendaftar program tersebut.

Dalam kenyataan dengan sistem rekrutmen tersebut terdapat sisi negatif. Peserta dari perguruan tinggi di luar Pulau Jawa dengan predikat 5 tertinggi tersebut tidak sebanding 
dengan mahasiswa dari Pulau Jawa. Artinya kualitas dan kuantitas mahasiswa dengan predikat lima tertinggi tersebut tidak setara/ekuivalen dengan mahasiswa yang berasal dari Pulau Jawa. Akibatnya beban perguruan tinggi menjadi lebih berat karena harus melakukan program tambahan atau remidial untuk menyetarakan dengan mahasiswa lainnya agar tidak terlalu ketinggalan dalam mengikuti pelaksanaan perkuliahan. Namun dari sisi keterwakilan kewilayahan dapat tercapai, karena diikuti oleh Perguruan Tinggi dari Luar Jawa.

Akan tetapi ketika melihat daftar mahasiswa di atas, keterwakilan wilayah juga belum terpenuhi untuk wilayah, Jawa, Madura, Bali, Sumatera, Kalimantan, Sulawesi, dll. Bila dilihat dari ketiga angkatan Pulau Jawa masih mendominasi. Sementara untuk input mahasiswa, dari ketiga angkatan di atas mereka berasal dari Perguruan Tinggi Keagamaan Islam baik negeri maupun swasta. Dengan sistem rekrutmen di atas, mahasiswa yang dari luar Pulau Jawa merasa beruntung, karena memiliki kesempatan yang sama, akan tetapi bagi mahasiswa dari ibukota harus tetap menunggu kesempatan selanjutnya.

Jadi Pelaksanaan rekrutmen calon mahasiswa Program 5000 Doktor yang diselenggarakan langsung oleh Perguruan Tinggi Penyelenggara dalam hal ini Institut PTIQ, sesuai dengan ketentuan sebagaimana tertuang dalam MOU. Dari ketiga angkatan rekrutmen tersebut dilakukan penyempurnaan mengingat pada angkatan pertama hanya diikuti oleh calon mahasiswa dari perguruan tinggi di Jawa. Hal ini dinilai kurang tepat sasaran karena mahasiswa peserta tes program ini, tidak diikuti oleh peserta dari Perguruan Tinggi dari luar Pulau Jawa. Di sisi lain program strategis Kemenag tidak tepat sasaran karena tidak ada perwakilan mahasiswa calon penerima beasiswa dari luar pulau Jawa. Ini merupakan bagian evaluasi dari pelaksanaan program strategis yang langsung dilakukan di awal program tersebut baru berjalan, yaitu Tahun 2017 dan 2018 ada perubahan dalam sistem rekrutmennya.

\section{Proses Pembelajaran}

Pelaksanaan proses belajar mengajar mahasiswa Program 5000 Doktor pada Institut PTIQ dirancang sebagai perkuliahan yang biasa dilakukan pada perguruan tinggi tersebut. Pengaturan pelaksanaannya menjadi tanggung jawab Ketua Program Studi (kaprodi) Dr. Nur Arfiyah Febriani, M.A., meliputi jenis mata kuliah, topik bahasan dan dosen pengampu setiap mata kuliah, waktu pelaksaan kuliah, baik waktu maupun hari belajar setiap minggunya serta metodologi perkuliahan dari setiap dosen pengampu mata kuliah. Selain itu disusun juga jadwal konsultasi bagi setiap mahasiswa untuk penyelesaian disertai mulai dari rencana penyusunan proposal, seminar proposal, penentuan promotor dan co-promotor, serta bimbingan lainnya yang diperlukan.

Hal ini dipersiapkan agar kaprodi dapat dengan mudah melakukan pemantauan untuk mengetahui secara berkala, capaian-capaian perkuliahan dan proses penyelesaian disertasi setiap mahasiswa. Dengan demikian, hambatan atau kendala yang ditemukan pada saat pelaksanaan perkuliahan dapat segera diperbaiki sedini mungkin, untuk menghindari kemungkinan tidak tercapainya program dan tidak tepat sasaran dalam upaya memenuhi target capaian waktu pelaksaan sebagaimana tertera dalam MOU antara Diktis selaku pemberi beasiswa dengan Institut PTIQ selaku salah satu perguruan tinggi Penyelenggara Program 5000 Doktor.

Pelaksanaan perkuliahan diselenggarakan pada hari Senin sampai Kamis dan Sabtu (sesuai jadwal perkuliahan di atas) dan pelaksanaannya pada kelas khusus tidak digabung dengan kelas reguler. Hari-hari lainnya diliburkan untuk memberi kesempatan kepada mahasiswa untuk mengumpulkan bahan kepustakaan, menyusun rancangan tulisan, baik makalah maupun disertasi serta untuk keperluan konsultasi baik dengan dosen pengampu mata kuliah maupun dengan pembimbing/promotor dan $\mathrm{Co}_{-}$ promotor.

Pada saat penelitian ini dilakukan dapat diperoleh informasi dari kaprodi, bahwa program kegiatan perkuliahan mahasiswa untuk mahasiswa tahun 2016 sedang mempersiapkan penyusunan disertasi, bahkan sudah ada yang ujian proposal. Sementara mahasiswa angkatan tahun 2017 dan 2018 
masih dalam proses pelaksanaan perkuliahan. Dalam kaitan ini kaprodi selaku penanggung jawab pelaksana teknis dan akademis terus memantau proses perkuliahan/pembelajaran dengan cermat serta memberikan support kepada mahasiswa, dengan harapan Perkuliahan Program 5000 Doktor bisa dilaksanakan tepat waktu sesuai dengan kontrak yang telah disepakati antara Diktis dan Direktur Pasca Sarjana Institut PTIQ.

Sebagai catatan akademis dari Kaprodi Perkuliahan Program 5000 Doktor, bahwa kendala yang dihadapi, yaitu mahasiswa yang berasal perguruan tinggi di Pulau Jawa cenderung lebih cepat menerima perkuliahan dibanding dengan mahasiswa dari Perguruan Tinggi yang berasal dari luar Pulau Jawa. Hal ini sebagaimana telah diuraikan pada bagian rekrutmen mahasiswa dan kualifikasi rangking yang dicapai oleh mereka yang berasal dari perguruan tinggi di luar Pulau Jawa dan dari luar Pulau Jawa (Wawancara dengan Kaprodi Studi Ilmu Alquran dan Tafsir "Penanggung Jawab Program 5000 Doktor" Dr. Nur Arfiyah Febriani, MA, Tanggal 26 Oktober 2018).

\section{Kelemahan dan Kelebihan}

Penyelenggaraan program doktor pada sebuah perguruan tinggi, merupakan suatu indikasi bahwa lembaga pendidikan tersebut telah memiliki kualifikasi akademis untuk menyelenggarakan program pasca sarjana dalam bidang keilmuan yang menjadi kajian utama/spesifik di perguruan tinggi tersebut. Tidak setiap perguruan tinggi dapat menyelenggarakan program pasca sarjana, apalagi sampai peringkat strata tiga atau program doktor, sebagai puncak dari penyelenggaraan kajian keilmuan di sebuah perguruan tinggi.

Untuk dapat menyelenggarakannya diperlukan persyaratan akademis dan administratif yang cukup ketat. Persyaratan tersebut harus terlebih dahulu dinilai oleh sebuah Tim Asesor yang terdiri dari para guru besar dalam bidangnya. Berdasarkan hasil penilaian para guru besar tersebut, baru ditetapkan oleh Instansi berwenang dapat atau tidaknya menyelenggarakan program pasca sarjana. Untuk perguruan tinggi agama tentu kewenangannya ada pada Kementerian Agama.
Dalam kaitan ini, penyelenggaraan Program 5000 Doktor bagi Institut Perguruan Tinggi Ilmu Alquran tentu memiliki nilai positif atau negatif, bagi perguruan tinggi sendiri dan mahasiswa. Hal ini mengingat pelaksanaannya dikaitkan dengan program strategis yang merupakan kebijakan dari Kementerian Agama c/q Dirjen Diktis.

\section{Perguruan Tinggi}

Sebuah program ketika dilaksanakan tentunya memiliki kelemahan dan kelebihan. Dalam hal kelemahannya, diharapkan dapat dijadikan sebuah dorongan dan motivasi untuk terus meningkatkan kualitas akademis dalam pelaksanaan Penyelenggaraan Program 5000 Doktor sebagai realisasi kerja sama dengan Dirjen Diktis. Hal ini penting untuk diperhatikan agar Institut PTIQ yang sudah memiliki kepercayaan akademis terus menjaga kualitas, bahkan meningkatkannya agar amanah pelaksanaan program ini mencapai tujuannya yaitu peningkatan kualitas dosen di perguruan tinggi agama.

Keberhasilan secara akademis dalam pelaksanaan Program 5000 Doktor ini diharapkan Institut PTIQ sebagai perguruan tinggi yang mengkaji secara khusus bidang Alquran menjadi perguruan tinggi yang unggul dan model perguruan tinggi yang menjadi acuan perguruan tingi lainnya. Dengan demikian kerja sama ini memiliki nilai tambah yang dapat diambil manfaatnya bagi perguruan tinggi sebagai lembaga untuk pengembangan civitas akademika. Di antara kelebihan yang diperoleh Institut PTIQ sebagai lembaga adalah support dana yang dikelola dengan baik dan secara maksimal dimanfaatkan untuk penyelenggaraan kegiatan ini, sesuai dengan peruntukannya.

\section{Mahasiswa}

Bagi mahasiswa peserta Program 5000 Doktor juga memiliki sisi plus minusnya. Sisi kekurangannya dari penilaian penyelenggara program, bahwa kualifikasi mahasiswa dari perguruan tinggi luar Jawa berada di bawah kualifikasi mahasiswa dari perguruan tinggi di Pulau Jawa. Sebagai contoh mahasiswa yang memiliki nilai sama (A) namun dari perguruan tinggi yang berbeda dari Pulau Jawa dengan luar pulau Jawa, karena standar yang digunakan 
bisa jadi berbeda. Namun demikian perbedaan atau kekurangan tersebut justru dapat memicu untuk belajar lebih giat lagi, agar bisa menyamai rekan-rekan seangkatannya dalam belajar, melalui penelusuran sumber-sumber utama dan atau referensi bagi pendalaman bidang-bidang yang dikaji.

Hal ini penting agar program ini berhasil dengan baik. Keberhasilan itu tentu akan berdampak bagi mahasiswa peserta Program 5000 Doktor, dan juga bermanfaat bagi perguruan tinggi penyelenggara dalam menghasilkan produk dosen berkualifikasi strata tiga, dalam hal ini Institut PTIQ. Sedang bagi mahasiswa peserta Program 5000 Doktor akan mendapat predikat akademis yang lebih tinggi, strata tiga/Doktor yang akan dibutuhkan dan sekaligus meningkatkan kualifikasi diri dosen sendiri dan berdampak pada peringkat perguruan tinggi tempat dosen tersebut mengajar.

Adapun kelemahan lainnya, ditinjau dari sisi minimnya biaya program perkuliahan. Untuk setiap mahasiswa (hanya) memperoleh beasiswa sebesar empat juta rupiah/bulan, untuk biaya akomodasi dan konsumsi, biaya pengadaan referensi dan biaya penelitian. Biaya tersebut bisa dikatakan masih minim dibandingkan dengan kebutuhan untuk menyelesaikan program doktor. Tentu hal ini berpulang kepada mahasiswa sendiri untuk dapat menyiasatinya, agar dapat menyelesaikan program tersebut tepat waktu. Selain itu, waktu yang ditetapkan hanya dalam tempo 3 tahun, padahal beasiswa dari lembaga lain, untuk program doktor diberi batas waktu hingga 4 tahun. Karena kebutuhan yang berbeda idealnya, bagi peserta dalam kota dan luar kota juga disesuaikan dengan kebutuhan realnya agar lebih semangat lagi dalam menyelesaikan kuliah sesuai program. Namun demikian bila tidak memenuhi ketentuan patut diberi sanksi akademis.

Sedang sisi kelebihannya, bahwa kajian bidang Alquran dan keilmuan terkait dengannya, masih relatif sedikit yang dilakukan perguruan tinggi dengan predikat akademis strata 3/doktor. Karena bidang kajian Alquran dan ilmu terkait di perguruan tinggi masih bisa dikatakan langka, hanya tiga perguruan tinggi, yaitu UIN Jakarta, Yogyakarta dan Surabaya
(Lilik Umiyati, 2012), maka tentu akan banyak dibutuhkan dan dicari oleh perguruan tinggi, dan pada waktu yang sama akan mengangkat predikat dosen di kalangan masyarakat perguruan tinggi pada umumnya.

Secara sosiologis, keinginan untuk menempuh pendidikan yang paling tinggi merupakan dambaan setiap orang terutama bagi dosen-dosen yang ingin meningkatkan kualitas SDM. Keinginan tersebut, tidak semua orang dapat meraihnya. Oleh karena itu bagi mahasiswa yang lulus seleksi merupakan kebanggaan tersendiri bisa kuliah gratis, dan itu sebagai sebuah kelebihan bagi mahasiswa.

Dosen adalah salah satu unsur penting dalam pembangunan nasional karena dosen adalah agen perubahan di bidang Pendidikan (Harto, 2018). Menurut Undang-Undang Republik Indonesia Nomor 14 tahun 2005 tentang guru dan dosen, dosen adalah pendidik profesional dan ilmuwan dengan tugas utama mentransformasikan, mengembangkan, dan menyebarluaskan ilmu pengetahuan, teknologi, dan seni melalui pendidikan, penelitian. Oleh karena Itu Kementerian Agama dalam hal ini Ditjen Diktis sudah sangat tepat memberikan beasiswa kepada Dosen Perguruan Tinggi Keagamaan Islam baik negeri maupun swasta. Dalam rangka peningkatan mutu PTKI dan SDM.

Berdasarkan data-data yang dihimpun dari berbagai sumber informasi sesuai dengan penelitian kualitatif dalam penyelenggaraan Program 5000 Doktor, program unggulan Ditjen Diktis ditinjau dari berbagai aspek pelaksaan kegiatan, baik akademis, administratif serta mekanismenya telah memenuhi persyaratan yang telah ditetapkan, sesuai mekanisme kerja sama antara Diktis dan Perguruan Tinggi Penyelenggara dalam hal ini Institut PTIQ. Persyaratan tersebut yang harus dipenuhi yaitu, Perguruan Tinggi Penyelenggara telah memiliki Supervisor Ahli dalam Bidang Kajian yang akan dipelajari, dan memiliki reputasi baik, berdasarkan perangkingan perguruan tinggi.

Untuk mengikuti program ini, untuk tiga angkatan (2016-2017; 2017-2018, 2018-2019) mengundang mahasiswa dari berbagai Provinsi di kawasan Pulau Jawa yaitu, Perguruan Tinggi di Jawa Barat, Jawa Tengah, Jawa Timur, 
Banten; kawasan Sumatera yaitu Sumatera Utara, Sumatera Barat, Riau, Sumatera Selatan, Lampung dan Bangka Belitung; kawasan Tengah, Kalimantan Selatan dan Kalimantan Barat; sedang kawasan timur Sulawesi Tengah, tidak termasuk dari Maluku dan Papua. Mereka yang direkrut adalah dosen-dosen yang mengajar di PTKI baik negeri maupun swasta.. Jumlah mahasiswa untuk tiga angkatan tersebut sebanyak 15 dosen.

Pelaksanaan rekrutmen calon mahasiswa Program 5000 Doktor yang diselenggarakan langsung oleh Perguruan Tinggi Penyelenggara dalam hal ini Institut PTIQ, sesuai dengan ketentuan sebagaimana tertuang dalam MOU. Dari ketiga angkatan rekrutmen tersebut dilakukan penyempurnaan mengingat pada angkatan pertama hanya diikuti oleh calon mahasiswa dari perguruan tinggi di Jawa. Hal ini dinilai kurang tepat sasaran karena mahasiswa peserta tes program ini, tidak diikuti oleh peserta dari Perguruan Tinggi dari luar Pulau Jawa. Di sisi lain program strategis Kemenag tidak tepat sasaran karena tidak ada perwakilan mahasiswa calon penerima beasiswa dari luar pulau Jawa. Ini merupakan bagian evaluasi dari pelaksanaan program strategis yang langsung dilakukan di awal program tersebut baru berjalan, yaitu Tahun 2017 dan 2018 ada perubahan dalam sistem rekrutmennya.

Sedang kriteria kelulusan ditentukan oleh nilai tertinggi yang dicapai oleh 10 mahasiswa peserta tes. Dalam kaitan ini, dievaluasi pula bahwa nilai kelulusan tersebut masih ada catatan, bahwa kualifikasi dosen-dosen yang berasal dari perguruan tinggi di Pulau Jawa pada umumnya lebih baik dibanding dengan dosen-dosen yang berasal dari luar pulau Jawa. Sehingga dengan demikian untuk pemerataan peningkatan kualitas perguruan tinggi di luar Pulau Jawa dengan program 5000 doktor belum bisa dicapai pula mengingat mahasiswa yang ikut dalam program ini masih terbatas. Untuk hal ini pun dilakukan evaluasi dengan menyelenggarakan kuliah tambahan atau remedial bagi bidang-bidang tertentu yang terkait dengan program studi yang akan ditempuh dalam hal ini Ilmu tafsir, Remedial tersebut menjadi tanggung jawab pihak Perguruan Tinggi Penyelenggara.
Sebagai evaluasi langsung dari ketimpangan sistem seleksi ini, penyelenggaraannya langsung oleh Diktis, dengan bahan ujian dari masing-masing Perguruan Tinggi penyelenggara sesuai dengan program studinya. Hasil tes dengan nilai 5 tertinggi dapat diterima di Perguruan Penyelenggara tempat mahasiswa mendaftar program tersebut. Namun demikian pada kenyataannya dengan sistem rekrutmen ini masih ada segi negatifnya, peringkat 5 tertinggi dari mahasiswa di luar Pulau Jawa tidak sebanding dengan mahasiswa dari Pulau Jawa. Artinya kualitas dan kuantitas mahasiswa dengan predikat 5 tertinggi tersebut tidak setara dengan mahasiswa yang berasal dari Pulau Jawa.

Untuk hal ini pun dilakukan evaluasi dengan menyelenggarakan kuliah tambahan atau remedial bagi bidang-bidang tertentu yang terkait dengan program studi yang akan ditempuh, untuk menyetarakan dengan mahasiswa lainnya agar tidak terlalu ketinggalan dalam mengikuti pelaksanaan perkuliahan. Hal ini menjadi tanggung jawab pihak perguruan tinggi penyelenggara.

Hal tersebut di atas beberapa aspek yang dilakukan agar kualitas lulusan Program 5000 Doktor dapat tercapai dengan baik sebagai program strategis Diktis dalam upaya meningkatkan kualitas perguruan tinggi yang setara di seluruh kawasan. Hal lain terkait dengan kualifikasi dosen baik jumlah maupun keahliannya untuk mengampu bidang studi yang dikaji sesuai dengan keahliannya dan juga dengan jumlah yang sudah tercukupi.

\section{PENUTUP}

Dari uraian di atas dapat disimpulkan bahwa Penyelenggaraan Program 5000 Doktor yang dilaksanakan oleh Institut PTIQ Jakarta telah dilaksanakan dengan mengikuti prosedur dan tahapan-tahapan sebagaimana tertuang dokumen MOU antara Diktis dan Institut PTIQ Jakarta, baik dalam hal teknis administrasi dan manajemen pelaksanaan maupun dalam hal teknis akademis penyelenggaraan perkuliahan sesuai dengan program yang ditawarkan oleh Institut PTIQ.

Kondisi mahasiswa selama tiga tahun berturut-turut relatif tetap, sesuai dengan porsi 
yang ditetapkan oleh Dirjen Diktis Kementerian Agama, sementara kurikulum yang digunakan mengacu pada kurikulum pemerintah dan Institut PTIQ Jakarta yaitu Program Studi Ilmu Alquran dan Tafsir. Sedang dosen yang mengampu sesuai dengan standar yang ditetapkan oleh Undang-Undang Republik Indonesia Nomor 14 Tahun 2005 tentang Guru dan Dosen (Lembaran Negara Republik Indonesia Tahun 2005 Nomor 157, Tambahan Lembaran Negara RI Nomor 4586). Yang berjumlah 8 orang dosen bergelar Profesor Akademik, 22 orang bergelar Doktor (S3) dan 7 orang dosen tamu.

Pelaksanaan rekrutmen mahasiswa calon penerima beasiswa Program 5000 Doktor yang diselenggarakan oleh Institut PTIQ ada sedikit perubahan dari apa yang telah ditetapkan pada dokumen MOU Penyelenggaraan Perkuliahan. Perubahan tersebut dilakukan Untuk memenuhi keterwakilan peserta beasiswa dari luar Pulau Jawa. Maka untuk rekrutmen mahasiswa angkatan tahun 2017-2018 terjadi perubahan, bahwa seleksi peserta beasiswa, yang semula dilakukan oleh perguruan tinggi menjadi Penyelenggaraannya dilakukan oleh Diktis meskipun soalnya dibuat oleh perguruan tinggi bersangkutan. Perubahan tersebut sedikit menyimpang dari MOU, yang menyatakan bahwa perguruan tinggi menyelenggarakan seleksi peserta beasiswa program 5000 doktor. Sebagai efek dari perubahan tersebut, ternyata kualifikasi mahasiswa yang berasal dari perguruan tinggi di Pulau Jawa lebih unggul dibanding dengan mahasiswa yang berasal dari perguruan tinggi di luar Pulau Jawa. Kondisi ini menjadi tanggung jawab Perguruan Tinggi, untuk mengatasi ketimpangan perguruan tinggi dalam hal ini melalui kaprodi memberikan remedial/penugasan-penugasan agar kemampuan mahasiswa tidak terlalu timpang.

Hal lain terkait dengan pelaksanaan teknis perkuliahan dan pencapaian target belajar di bawah tanggung jawab kaprodi Pelaksana Perkuliahan Program 5000 Doktor. Kaprodi senantiasa memberikan motivasi kepada mahasiswa, untuk senantiasa bisa menyelesaikan perkuliahan tepat waktu.

Berkenaan dengan anggaran atau beasiswa yang terkait dengan biaya mahasiswa, dirasa belum mencukupi. Biaya yang berkisar diangka empat juta rupiah harus dicukupkan untuk biaya domisili, makan dan minum, biaya pengadaan buku referensi, serta biaya penelitian. Oleh karena itu perlu pembedaan antara mahasiswa yang berdomisili DKI Jakarta, Jawa (Tengah, Barat, Timur), dan luar Jawa. Temuan yang menarik adalah ketika mahasiswa sudah menyelesaikan perkuliahan tatap muka, otomatis mereka kembali ke daerah masing-masing, terkadang mereka lupa akan tugas penyelesaian penulisan disertasi. Hal tersebut kaprodi selalu aktif menghubungi dan mengingatkan para mahasiswa, untuk segera menyelesaikan disertasinya.

Dari uraian di atas direkomendasikan bahwa program 5000 doktor pada Kementerian Agama RI. berjalan sesuai dengan prosedur penyelenggaraan, oleh karena itu program tersebut perlu diteruskan dalam rangka meningkatkan kualitas dan profesionalisme dosen dan tenaga kependidikan yang memiliki kontribusi besar bagi terjaminnya proses yang bermutu di lingkungan Perguruan Tinggi Keagamaan Islam (PTKI). Namun demikian perlu perbaikan dalam hal program penyelenggaraannya (Kementerian Agama RI). Perbaikan tersebut terkait beberapa hal, yaitu: Pertama dalam rangka untuk meningkatkan mutu lulusan hendaknya pemberian beasiswa program 5000 doktor hendaknya diperpanjang satu tahun, yang sedianya pemberian beasiswa hanya tiga tahun menjadi empat tahun. Hal tersebut dalam rangka untuk memaksimalkan mahasiswa untuk mencapai kelulusan yang sesuai harapan, terutama bagi mahasiswa yang datang dari luar Jawa. Kedua, perlu perbaikan pada sistem rekrutmen peserta, seyogyanya seleksi peserta dilakukan oleh lembaga/institusi (dikembalikan seperti semula) meskipun Diktis yang menentukan siapa yang berhak lulus seleksi. Oleh karena itu perlu revisi regulasi terkait dengan rekrutmen mahasiswa program 5000 doktor. Ketiga, Biaya Mahasiswa yang di dalam anggaran tertulis hanya empat juta rupiah hendaknya diberikan kenaikan, mengingat biaya empat juta setelah dipotong biaya penelitian satu juta, mahasiswa hanya menerima tiga juta per bulan. Hal tersebut dirasa kurang mencukupi untuk biaya hidup dan kebutuhan akan referensi. Oleh karena itu perlu peninjauan ulang terkait dengan alokasi anggaran untuk 
mahasiswa, terutama bagi mahasiswa yang berasal dari luar Jawa.

\section{UCAPAN TERIMAKASIH}

Dengan diterbitkannya jurnal ini penulis menyampaikan ucapan terima kasih kepada 1) Kepala Pusat Penelitian dan Pengembangan Pendidikan Agama dan Keagamaan Kementerian Agama; 2) Direktur Program Pasca Sarjana Institut PTIQ Jakarta; 3) Ketua Program Studi Ilmu Alquran dan Tafsir Institut PTIQ Jakarta; 4) para mahasiswa Program 5000 Doktor Institut PTIQ Jakarta; 5) seluruh jajaran dosen dan staf pada Program Pascasarjana Institut PTIQ; dan 6) semua pihak yang tidak dapat disebutkan satu persatu yang telah membantu memberikan dukungan dalam pelaksanaan penelitian dan penyusunan artikel ini.

\section{DAFTAR PUSTAKA}

Agustanico Dwi Maryadi. (2017). Model Evaluasi Pembelajaran Dalam Penelitian Evaluasi. Jurnal Ilmiah Penjas, 3.

Aman. (2012). Pengembangan Model Evaluasi Program Pembelajaran Sejarah Di Sma. Penelitian Dan Evaluasi Pendidikan, Vol. $16, N$.

Arikunto, S., \& Abdul Jabar, C. S. (2010). Evaluasi Program Pendidikan, Pedoman Teoritis bagi Praktisi Pendidikan. Jakarta: Bumi Aksara.

Brinkerhoff, R. O., Brethower, D. M., Hluchyj, T., \& Nowakowski, J. R. (1983). Program Evaluation. Springer Netherlands. https://doi.org/10.1007/978-94-011$6757-4$

Crawford, J. (2000). Evaluation of Library and Information Services (2nd ed.). Aslib, The Association for Information Management.

Dedi Lazwardi. (2017). Implementasi Evaluasi Program Pendidikan Di Tingkat Sekolah Dasar Dan Menengah. Al-Idarah, Vol. VII/I.

Dewa Gede Hendra Divayana, G. A. D. S. (2016). Evaluasi Program Sertifikasi Komputer Pada Universitas Teknologi Indonesia Menggunakan Model Cse-
Ucla. Jurnal Pendidikan Indonesia, Vol.5/2.

Diktis. (2014). Pedoman Pelaksanaan 5000 Doktor. In Buku Pedoman.

Djaali, H., \& Muljono, P. (2008). Pengukuran dalam Bidang Pendidikan. Jakarta: Grasindo.

Pidato Presiden RI pada MTQ Nasional III di Banjarmasin, (1970).

https://ptiq.ac.id. (2012). Sejarah PTIQ.

Husen Hasan Basri, DO Penelitian Evaluasi 5000 Doktor, (2018).

Kasinyo Harto. (2018). Tantangan Dosen PTKI di Era Industri 4.0. Jurnal Tatsqif: Jurnal Pemikiran Dan Penelitian Pendidikan, Vol. 16/1.

Lilik Umiyati, dkk. (2012). Peta Kajian Ilmu Alquran di PTKI. PPIM UIN Jakarta.

Mahirah B. (2017). Evaluasi Belajar Peserta Didik (Siswa). Jurnal Idaarah, Vo.1/2.

M Echols, J., \& Shadily, H. (2000). Kamus Inggris Indonesia. Gramedia Pustaka Utama.

ME. Anwar. (2014). Menelusuri Kebijakan Pendidikan Islam Di Indonesia. Edukasi Islami Jurnal Pendidikan Islam, Vol. 3.

PTIQ. (2012). Sejarah Institute PTIQ (p. https://ptiq.ac.id).

R. Worthen, B., \& R. Sanders, J. (1973). Educational Evaluation: Theory and Practice. Wadsworth Publishing Company.

Stufflebeam, D. L. (1968). Evaluation as Enlightenment for Decision-making. Evaluation Center, Ohio State University, 1968.

Sudjana, N., \& Rivai, A. (2009). Teknologi Pengajaran (V). Sinar Baru Algensindo.

Syefudin. (2019). Pengaruh Kualitas Layanan Akademik Dan Kinerja Dosen Terhadap Kepuasan Mahasiswa Pascasarjana Institut Perguruan Tinggi Ilmu Alquran (Ptiq) Jakarta. Jurnal Andragogi:Pendidikan Islam Dan Menejemen Pendidikan, Vol. 1. 
Tague-Sutcliffe, J. M. (1996). Some perspectives on the evaluation of information retrieval systems. Journal of the American Society for Information Science, $\quad 47(1), \quad 1-3$. https://doi.org/10.1002/(SICI)10974571(199601)47:1.1::AIDASI1.3.0.CO;2-3

Teni Aryanti, Supriyono, M. I. (2015). Evaluasi Program Pendidikan Dan Pelatihan. Jurnal Pendidikan Nonformal UNM Malang, Vol.10/1.

Umayah, U. (2016). Tafsir Maqashidi : Metode Alternatif Dalam Penafsiran Alquran. Diya Al-Afkar : Jurnal Studi Alquran Dan Hadis, Vol.4/1.
Uzer Usman, M. (2003). Menjadi Guru Profesional. Remaja Rosdakarya.

Wahyudhiana, D. dan. (2015). Model Evaluasi Program Pendidikan. ISLAMADINA, Vol. $X I V$.

Woods, J. D. (1988). Curriculum Evaluation Models : Practical Applications for Teachers. Australian Journal of Teacher Education, $13(1)$. https://doi.org/10.14221/ajte.1988v13n2. 1

Yunanda, M. (2009). Evaluasi dalam Islam. Bumi Aksara. 